\title{
ЗАКОНОМЕРНОСТИ ФОРМИРОВАНИЯ ГИДРОГЕЛЕЙ НА ОСНОВЕ L-ЦИСТЕИНА, N-АЦЕТИЛ-L-ЦИСТЕИНА И НИТРИТА СЕРЕБРА
}

\author{
Д.В. Аверкин ${ }^{1,2}$, Д.В. Вишневецкий' , Т.В. Перевозова'
}

${ }^{1}$ Кафедра физической химии, Тверской государственный университет, 170100, Россия, Тверь, Желябова, 33.

2Лаборатория метрологического обеспечения дисперсных параметров аэрозолей, взвесей и порошкообразных материалов, Всероссийский научно-исследовательский институт физико-технических и радиотехнических измерений,

141570 , Россия, Московская область, Солнечногорский район, г.п. Менделеево

DOI: 10.19163/MedChemRussia2021-2021-372

E-mail: averkindmitry@gmail.com

Исследования в области молекулярной самосборки продолжают притягивать внимание ученых всего мира. Это связано с многообразием возможных структур, формирующихся при самоорганизации, и соответственно, с их различными конечными свойствами. Недавно коллектив авторов ТвГУ открыл новую супрамолекулярную гель-систему, содержащую наночастицы серебра (НЧС), используя один из подходов зеленых нанотехнологий [1]. Был выдвинут возможный механизм самоорганизации, а также показаны некоторые биоактивные свойства гелевой композиции.

В настоящей работе объектами изучения стали системы, полученные смешением водных растворов низкой концентрации на основе серосодержащих аминокислот - L-цистеина (ЦИС) и $\mathrm{AgNO}_{2}$, а также N-ацетил-L-цистеина (НАЦ) и $\mathrm{AgNO}_{2}$. В ходе эксперимента варьировались концентрации исходных компонентов и их соотношение. Синтезированные системы были исследованы методами УФ-спектроскопии, динамического рассеяния света, измерения дзета-потенциала и проводимости, сканирующей электронной микроскопии и элементного анализа, просвечивающей электронной микроскопии.

Установлено, что химическая природа аминокислоты существенно влияет на возможность получения одновременно обратимого геля и НЧС в его матрице. Это характерно для системы с ЦИС и не характерно для НАЦ. Изменение концентрации исходных компонентов и их соотношения позволяет контролировать конечные важные характеристики системы: вязкость, стабильность, дисперсность, форму и размеры НЧС, величину заряда агрегатов, концентрацию НЧС и индекс полидисперсности частиц.

Работа выполнена на оборудовании Центра коллективного пользования

Тверского государственного университета.

\section{Литература}

[1]. D.V. Vishnevetskii, A.R. Mekhtiev, T.V. Perevozova, D.V. Averkin, A.I. Ivanova, S.D. Khizhnyak and P.M. Pakhomov, Soft Matter, 2020, 16, 9669-9673. 